\title{
Organiczne zaburzenia urojeniowe u pacjentki po przeszczepie nerki - opis przypadku
}

\author{
Psychotic disorder with delusions due to a known physiological condition in a patient after \\ kidney transplant - a case report
}

\author{
Agata Bąba-Kubiś ${ }^{凶}$, Justyna Pełka-Wysiecka, Paweł Liśkiewicz, Michał Wroński, Jerzy Samochowiec
}

Pomorski Uniwersytet Medyczny w Szczecinie, Katedra i Klinika Psychiatrii, ul. Broniewskiego 26, 71-460 Szczecin

Pomeranian Medical University in Szczecin, Department of Psychiatry

$\bowtie$ agata0621@gmail.com

\begin{abstract}
Introduction: This paper presents the case of a patient diag nosed with organic delusional disorder. Medical history revealed that the psychiatric symptoms increased gradually after the patient received a renal transplant from a deceased donor. Case report: A 42-year-old patient was admitted to a psychiatric ward for observation and, if necessary, modification of prior clinical diagnosis.

Commentary: Psychotic symptoms in the form of delusions of reference, persecution, and auditory hallucinations occurred a few weeks after the renal transplantation from a deceased donor. The intensity of these symptoms had the tendency to increase. At that time the patient was treated with increased
\end{abstract}

doses of immunosuppressive medications, in line with post-transplant treatment standards. Dose reductions had no observable effect on the psychiatric symptoms. The patient is also suffering from Hashimoto thyroiditis, hypertension, hepatitis type B, thrombosis of internal carotid artery, and diabetes mellitus type 2 with nephropathy, retinopathy, and neuropathy. Conclusions: This case report is an example of the multifactorial aetiology of psychopathological symptoms. It also shows the need to consider many aspects of the patient's somatic state while determining psychiatric diagnosis and planning treatment. Keywords: psychotic disorders; renal transplantation; immunosuppressive medications; systemic lupus erythematosus.

\begin{abstract}
ABSTRAKT
Wstęp: W niniejszym artykule przedstawiono przypadek pacjentki chorującej na organiczne zaburzenia urojeniowe. Początek objawów psychiatrycznych następował stopniowo w okresie kilku tygodni po przeszczepieniu pacjentce nerki od zmarłego dawcy.

Opis przypadku: 42-letnia pacjentka została przyjęta na oddział psychiatrii w celu obserwacji stanu psychicznego oraz ewentualnej modyfikacji postawionego wcześniej rozpoznania klinicznego. Komentarz: Objawy psychotyczne o charakterze urojeń ksobnych, prześladowczych oraz omamów słuchowych pojawiły się u pacjentki w okresie kilku tygodni po przeszczepie nerki od zmarłego dawcy. Objawy te miały tendencję do stopniowego nasilania się. Zgodnie ze standardami postępowania
\end{abstract}

potransplantacyjnego pacjentka przyjmowała zwiększone dawki leków immunosupresyjnych, jednak mimo redukcji dawek objawy psychotyczne nie uległy zmniejszeniu. Pacjentka obciążona była somatycznie chorobą Hashimoto, nadciśnieniem tętniczym, wirusowym zapaleniem wątroby typu B, zakrzepicą tętnicy szyjnej wewnętrznej, cukrzycą typu 2 powikłaną nefropatią, retinopatią i neuropatią.

Wnioski: Przedstawiony przypadek stanowi przykład wieloczynnikowej etiologii objawów psychopatologicznych oraz wskazuje na konieczność uwzględniania wielu aspektów stanu somatycznego przy ustalaniu diagnozy psychiatrycznej i planowaniu leczenia pacjenta.

Słowa kluczowe: zaburzenia psychotyczne; transplantacja nerki; leczenie immunosupresyjne; toczeń rumieniowaty układowy.

\section{WSTĘP}

Transplantologia jest gałęzią medycyny, która wciąż wzbudza dużo kontrowersji oraz emocji w społeczeństwie. Według danych Poltransplantu w 2016 r. liczba przeszczepionych nerek od zmarłych dawców wynosiła 978, natomiast liczba organów pobranych od żywych dawców - 50. W pierwszych 3 miesiącach 2017 r. przeszczepiono pacjentom 227 nerek od zmarłych dawców, natomiast jedynie 18 organów pobrano od żywych dawców. Według Poltransplantu celem udanego przeszczepienia narządu jest umożliwienie prowadzenia normalnego życia, kontynuowania nauki oraz podjęcia pracy przez pacjenta.
Biorcy przeszczepu nerki zwalniają miejsce dializacyjne innym osobom oczekującym na przeszczep. Ponadto nie bez znaczenia jest aspekt socjoekonomiczny transplantacji. Według najnowszych badań przeszczepienie nerek wymaga mniejszych nakładów finansowych niż dializoterapia. Podstawowym wskazaniem do transplantacji nerek jest ich przewlekła niewydolność w krańcowym stadium, definiowana objawowo jako spadek wielkości przesączania kłębuszkowego poniżej 20-25\%. Przeszczepienie nerki może przynieść poprawę w niemal każdym przypadku niewydolności narządu. W miarę możliwości stosuje się tzw. przeszczepy wyprzedzające (pre-emptive transplants), które pozwalają uniknąć dializoterapii. Ten rodzaj 
przeszczepów wykonywany jest coraz częściej u osób, które mają w rodzinie zgodnych dawców. Trzy najczęściej spotykane choroby prowadzące do uszkodzenia nerek to cukrzyca typu 2 (cukrzycowa choroba nerek), kłębuszkowe zapalenie nerek oraz nadciśnienie tętnicze. Do pozostałych znaczących przyczyn można zaliczyć: wielotorbielowatość nerek, chorobę Alporta, nefropatię immunoglobulinową, toczeń rumieniowaty, śródmiąższowe zapalenie nerek, odmiedniczkowe zapalenie nerek oraz uropatię zaporową $[1,2]$.

W Polsce, w zależności od przyjętych kryteriów, cechy niewydolności nerek występują u 6,9-16\% populacji [3], czyli u 2,7-6,2 mln osób [4]. W grupie pacjentów chorujących na przewlekłą niewydolność nerek oprócz zaburzeń depresyjnych stwierdzono również obecność czynników psychospołecznych, które znacznie ograniczały codzienne funkcjonowanie. Czynnikami tymi były m.in. wszelkie związane z chorobą sytuacje utraty, które dotyczyły zarówno sfery somatycznej, jak i psychologicznej. Obejmowały one utratę lub ograniczenie pełnienia ról społecznych i zawodowych, zmniejszenie dochodów, uzależnienie od personelu medycznego, konieczność przestrzegania diety oraz świadomość możliwych skutków przewlekłej choroby, ze zgonem włącznie [5]. Czynniki te przyczyniały się również do powstania poczucia utraty kontroli nad własnym życiem. Wykazano, że wyższe wskaźniki poczucia kontroli u chorych dializowanych znacznie zmniejszały prawdopodobieństwo wystąpienia depresji [6]. Zróżnicowany sposób radzenia sobie z chorobą zależy m.in. od cech osobowości, sposobu funkcjonowania przedchorobowego, czynników kulturowych oraz wsparcia społecznego. W nielicznych opracowaniach na ten temat podkreśla się, że zaburzenia psychiczne u pacjentów po przeszczepie nerki są podobne jak u osób chorujących na przewlekłą niewydolność nerek, jednak przeważnie o mniejszym nasileniu [7]. Wymieniane są tutaj m.in. zaburzenia depresyjne, lękowe, psychotyczne, zachowania samobójcze, zaburzenia snu oraz dysfunkcje seksualne [7, 8]. W piśmiennictwie podkreśla się fakt, iż wystąpienie depresji u biorcy przeszczepu nerki jest niezależnym czynnikiem ryzyka zwiększonej chorobowości, gorszego funkcjonowania przeszczepu, jego odrzucenia i konieczności powrotu do dializ, a także śmierci $[9,10,11,12]$. Za przyczyny występowania zaburzeń depresyjnych w tej grupie pacjentów uznaje się współistnienie czynników patofizjologicznych (np. nieprawidłowa funkcja przeszczepu, a następnie związana z tym toksemia mocznicowa czy też dyselektrolitemia itp.), psychologicznych (np. zmniejszenie autonomii i kontroli, strach przed możliwością odrzucenia przeszczepu w każdej chwili) oraz socjoekonomicznych (np. bezrobocie z powodu problemów chorobowych, mniejszy dochód) [7, 8, 13]. Nie bez znaczenia jest również wpływ leków immunosupresyjnych. Zarówno inhibitory kalcyneuryny (cyklosporyna, takrolimus), glikokortykosteroidy (prednizon, prednizolon, metyloprednizolon), jak i mykofenolan mofetilu, które są powszechnie stosowane po przeszczepie nerki, mogą wywoływać depresję, a także inne zaburzenia psychiczne, w tym psychotyczne $[8,14]$. Istnienie tak dużych wzajemnych powiązań pomiędzy chorobami nerek a stanem psychicznym zapoczątkowało rozwój psychonefrologii [7].
U większości pacjentów, u których po udanym przeszczepieniu nerki obserwowano uczucie lęku i objawy depresyjne, z czasem dochodziło do stopniowego zmniejszenia nasilenia objawów oraz poprawy stanu psychicznego i codziennego funkcjonowania. Natomiast skargi pacjentów dotyczące zaburzeń snu, wahania emocji czy zaburzeń percepcji i nastroju bardzo często współistniały z pulsami podawanych sterydów [14]. Badania częstości występowania zaburzeń psychicznych wykazały, iż jest ona większa u pacjentów przewlekle dializowanych niż w populacji ogólnej. Psychoza pojawiająca się po przeszczepie nerki była dość rzadko opisywana w czasopismach medycznych, istnieją jednak doniesienia, iż przeszczep nerki może predysponować pacjentów do zwiększonego ryzyka zachorowania na choroby psychiczne, w szczególności zaburzenia psychotyczne [15]. Ważną rolę przypisuje się w tych przypadkach lekom immunosupresyjnym używanym w transplantologii, do których zalicza się inhibitory kalcyneuryny, które mogą dawać neuropsychologiczne efekty uboczne w formie zaburzeń psychotycznych. Obecnie zaleca się, aby wszyscy kandydaci do zabiegu transplantacji nerki przechodzili badanie screeningowe w celu oceny stanu zdrowia psychicznego [16], szczególnie pod kątem zaburzeń depresyjnych [17]. W momencie ich stwierdzenia rekomenduje się podjęcie leczenia farmakologicznego, a dopiero następczo transplantacje.

\section{OPIS PRZYPADKU}

Pacjentka (42 lata, panna, bezdzietna, wykształcenie średnie, czynna zawodowo, przebywająca na świadczeniu rehabilitacyjnym, mieszkająca samotnie) objęta była opieką psychiatryczną od 2014 r. (I hospitalizacja psychiatryczna). Od tamtej pory była kilkukrotnie hospitalizowana na oddziale ogólnopsychiatrycznym. Każdorazowo po wypisie samodzielnie odstawiała zalecane leki z powodu subiektywnego braku poprawy samopoczucia. Podczas II hospitalizacji psychiatrycznej w 2015 r. wykonano badanie tomografii komputerowej głowy, następnie również badanie rezonansem magnetycznym (MR) głowy. Wykluczono proces rozrostowy, a potwierdzono obecność zmian organicznych, prawdopodobnie na tle naczyniowym. Pacjentka obciążona była somatycznie niedoczynnością tarczycy w przebiegu choroby Hashimoto, nadciśnieniem tętniczym oraz wirusowym zapaleniem wątroby typu B. Ponadto u kobiety w 12. r.ż. zdiagnozowano cukrzycę. Na jej tle rozwinęła się przewlekła choroba nerek, której powikłaniem pomimo leczenia insuliną była nefropatia cukrzycowa. Zaawansowane stadium nefropatii cukrzycowej było wskazaniem do przeszczepu nerki. Obecnie cukrzyca u pacjentki powikłana jest retinopatią i neuropatią.

W dniach 19-24 listopada 2015 r. chora była konsultowana przez psychiatrę na oddziale nefrologii. Na podstawie oceny stanu psychicznego postawiono wstępne rozpoznanie - „zaburzenia urojeniowo-omamowe, prawdopodobnie na podłożu organicznym", przy czym konsultant podkreślił, że bez dalszej diagnostyki nie można wykluczyć schizofrenii paranoidalnej. Pacjentkę skierowano na oddział psychiatrii (III hospitalizacja psychiatryczna) w celu przeprowadzenia diagnostyki 
oraz wdrożenia leczenia farmakologicznego. Dzięki wywiadowi zebranemu od pacjentki podczas przyjęcia do szpitala wiadomo, iż przeszczep nerki miał miejsce w ostatnim dniu kwietnia 2013 r., a od sierpnia tego roku dochodziło do stopniowego pogorszenia stanu psychicznego. Pacjentka podawała, że czuła się dręczona, wyzywana i oczerniana przez mieszkańców rodzinnego miasta. Obawiała się ludzi i przez cały czas miała wrażenie, że istnieje spisek skierowany przeciwko niej. Czuła się nagrywana i filmowana, pomimo zasłoniętych rolet nie czuła się bezpiecznie w swoim mieszkaniu. Wielokrotnie sprawdzała miejsce zamieszkania pod kątem podsłuchów, kamer, lecz nic nie znalazła. Pod oknami stale słyszała oczerniające ją głosy, szczególnie męskie, ale stopniowo dołączyły się głosy kobiece oraz dziecięce, które komentowały i obrażały pacjentkę. Z powodu zaistniałej sytuacji w ciągu kilku miesięcy obniżeniu uległ jej nastrój, ograniczyła wychodzenie z domu, z czasem pojawiły się myśli samobójcze i rezygnacyjne. Kobieta rozważała zmianę miejsca zamieszkania, ale z powodu zaciągniętego kredytu nie było to możliwe. Podczas przyjęcia na oddział psychiatrii lekarz dyżurny dokonał następującej oceny stanu psychicznego: „Pacjentka zorientowana prawidłowo wielokierunkowo. W chwili przeprowadzania badania w kontakcie logicznym. W zachowaniu okresowo napięta, drażliwa. Odpowiedzi na zadawane pytania miały rozwlekły, dygresyjny charakter. W nastroju obniżonym, afektywnie napięta. Na podstawie treści wypowiadanych przez pacjentkę można było stwierdzić obecność urojeń ksobnych, prześladowczych oraz okresową obecność halucynacji słuchowych. Pacjentka potwierdzała obecność myśli samobójczych w chwili badania, lecz przeczyła tendencji do ich realizacji. Przeczyła również obecności myśli rezygnacyjnych. Skarżyła się na zaburzenia apetytu, nie zgłaszała problemów ze snem".

\section{Autoanamneza}

Pytana o relacje rodzinne pacjentka niechętnie udzielała odpowiedzi, przyznając, że z matką „nigdy nie było relacji”. Ze strony ojca, który nadużywał alkoholu, pacjentka doświadczała przemocy psychicznej i fizycznej. Obecnie nie utrzymuje relacji z najbliższą rodziną. Zdobyła wykształcenie średnie, nie zdawała matury. Rozpoczęła pracę jako urzędniczka. Około 2005 r. zasłabła w pracy z powodu hipoglikemii, od tego momentu wg pacjentki zmianie uległa relacja pomiędzy nią a pracodawcą. Uważała, że złośliwie pyta ją o samopoczucie, sugerując zmianę stanowiska pracy na mniej obciążające. Z powodu rozpoczynających się problemów ze zdrowiem somatycznym pacjentka otrzymała półroczne zwolnienie lekarskie. Po powrocie do pracy w 2006 r. „zaczęły się problemy z nerkami”. W międzyczasie pacjentka zaciągnęła kredyt na mieszkanie w kamienicy, co „było spełnieniem jej marzeń”. W związku z problemami z nerkami pacjentka była pod stałą opieką ambulatoryjną Poradni Nefrologicznej. Ostatni rok przed przeszczepem uczęszczała na dializy, którym była poddawana do 30 kwietnia 2013 r., kiedy to została poinformowana o znalezieniu dawcy i planowanej operacji przeszczepu. Po przeszczepie pacjentka czuła się bardzo dobrze. Regularnie przyjmowała leki zalecone w Poradni Transplantacyjnej (Encorton, CellCept, Prograf) oraz pozostałe leczenie somatyczne. Po powrocie ze szpitala do mieszkania pacjentka zauważyła, że do lokalu naprzeciwko wprowadziło się 8 mężczyzn z firmy budowlanej z Radomia. Jak podaje, „wtedy też wszystko się zaczęło”. Po kilku tygodniach od momentu wprowadzenia się nowych lokatorów pacjentka zaczęła zauważać, że ludzie „dziwnie jej się przyglądają”, a na temat jej osoby krążą po mieście różnego rodzaju „niewybredne” komentarze. Według pacjentki obcy ludzie wiedzieli o niej wszystko, począwszy od jej zachowania w domu, a skończywszy na tym, co je na obiad. Wtedy też zaczęła podejrzewać, że w jej mieszkaniu zainstalowano kamery i podsłuchy, uważała, że ludzie przechodzący pod oknami komentowali jej zachowanie, a ktoś specjalnie wyprowadzał pod jej oknami psa, „by tam się załatwiał”. Będąc w sklepie, miała wrażenie, że mijający ją ludzie „ruszali nogami”, co wg niej miało sygnalizować, iż jest kobietą lekkich obyczajów. Była przekonana, że jest celowo poszturchiwana, że inni dziwnie się do niej uśmiechają oraz że stała się obiektem zainteresowania w swoim mieście. Kiedy znalazła na wycieraczce ulotkę reklamującą meble, uznała, że ktoś pozostawił ją celowo, wiedząc, że nie ma mebli kuchennych. Na próby sugestii, iż prezentowane przez nią skargi mogą być objawem choroby psychicznej, stawała się nerwowa, napięta, zaczynała płakać i podnosiła głos. Stanowczo przeczyła informacjom otrzymywanym od lekarzy, iż jej stan może być wynikiem stosowania leków immunosupresyjnych. Uważała, że jedyne źródło jej problemów tkwi w „miejscu, w którym mieszka”, a jedyna rzecz, która by jej pomogła, to zmiana miejsca zamieszkania, „nowe otoczenie, gdzie nikt jej nie zna i mogłaby zacząć wszystko od nowa”.

\section{Przebieg hospitalizacji}

W trakcie pobytu na oddziale psychiatrii w 2015 r. (III hospitalizacja psychiatryczna) pacjentka była skoncentrowana na stanie swojego zdrowia somatycznego, okresowo płaczliwa, drażliwa, reagująca złością przy próbie rozmowy na temat jej sytuacji życiowej. Podczas wdrażania farmakologicznego leczenia przeciwpsychotycznego bardzo drobiazgowo pilnowała liczby tabletek, wiążąc każde pogorszenie samopoczucia z przyjmowanym lekiem. Czas spędzała w sali i nie integrowała się z innymi pacjentami. W badaniu psychologicznym procesów poznawczych stwierdzono brak wskaźników przemawiających za występowaniem formalnych zaburzeń myślenia charakterystycznych dla procesu psychotycznego. Wykazano natomiast deficyty poznawcze sugerujące zmiany organiczne w obrębie centralnego układu nerwowego. Po blisko miesięcznej hospitalizacji pacjentka zdecydowała się opuścić oddział, zażądała wypisu wbrew zaleceniom lekarskim. Nie ustalono wówczas leczenia farmakologicznego, czyli ostatecznej oraz skutecznej dawki terapeutycznej leku przeciwpsychotycznego. Przy wypisie zaznaczono brak poprawy samopoczucia pacjentki. Występowała anozognozja. Po wypisie kobieta nie przyjmowała żadnych leków przeciwpsychotycznych i nie realizowała zaleceń lekarskich pomimo kilkukrotnych hospitalizacji psychiatrycznych. W 2016 r. została poddana VI hospitalizacji psychiatrycznej z powodu pogorszenia stanu psychicznego. Wykonano pacjentce kontrolne MR głowy, za pomocą którego nie 
stwierdzono zmian w obrębie ośrodkowego układu nerwowego (OUN) w porównaniu z badaniem z 2015 r. (II hospitalizacja psychiatryczna). Zaobserwowano natomiast obecność materiału zatorowego w tętnicy szyjnej wewnętrznej lewej. Pacjentka w związku z tym faktem była konsultowana neurologicznie, chirurgicznie, diabetologicznie, kardiologicznie oraz reumatologicznie. Zgodnie z zaleceniami wykonano angio-MR głowy z kontrastem, podczas którego wykazano w fazie tętniczej niedrożność tętnicy szyjnej wewnętrznej aż do zatoki jamistej (potwierdzono badaniem USG Dopplera). W związku z diagnozą zakrzepicy tętnicy szyjnej wewnętrznej lewej i wykluczeniem przyczyn kardiologicznych skutków zmian w obrębie OUN wysunięto podejrzenie układowej choroby tkanki łącznej. Konsultacja reumatologiczna nie wykazała odchyleń w badaniu przedmiotowym, zlecono wykonanie badań ANA (przeciwciała przeciwjądrowe) + panel APS (zespół antyfosfolipidowy), ANCA (przeciwciała przeciw cytoplazmie granulocytów obojętnochłonnych), antykoagulant toczniowy, $\mathrm{C}_{3}$ oraz $\mathrm{C}_{4}$ (składowe dopełniacza) oraz APRA (przeciwciała przeciw rybosomalnemu białku P). W uzyskanych wynikach laboratoryjnych przeciwciał uzyskano wartości prawidłowe wszystkich wymienionych miar przeciwciał oprócz przeciwciał APRA - miano dodatnie $24,40 \mathrm{RU} / \mathrm{mL}$ (norma $<20 \mathrm{RU} / \mathrm{mL}$ ). W badaniach laboratoryjnych zaleconych przez konsultującego neurologa stwierdzono poziom homocysteiny wynoszący 22,18 umol/L. Po konsultacji włączono suplementacje preparatami $\mathrm{B}_{12}$ i $\mathrm{B}_{6}$ oraz kwasem foliowym. Włączono leczenie przeciwkrzepliwe zgodnie z zaleceniem lekarza chorób wewnętrznych. Warto podkreślić fakt, że na oddziale konsultowano pacjentkę również diabetologicznie. Z powodu obawy przed nadmiernym przyrostem masy ciała ograniczała ona przyjmowanie posiłków, co było związane z koniecznością modyfikacji przyjmowanych dawek insuliny.

W związku z brakiem poprawy stanu psychicznego, pomimo modyfikacji leczenia farmakologicznego oraz utrzymujących się objawów psychotycznych pod postacią omamów słuchowych i urojeń, pacjentka została skierowana na oddział nefrologii w celu modyfikacji leczenia immunosupresyjnego (Prograf, CellCept, Encorton odstawiono w Klinice Psychiatrii). Z relacji lekarza prowadzącego oddziału nefrologii wynika, że pacjentka od samego początku była nieufna wobec planowanej modyfikacji leczenia i zgłaszała liczne dolegliwości somatyczne, które nie miały odzwierciedlenia w wynikach badań oraz w stanie somatycznym, a za które winą obarczała przyjmowane leki, zarówno internistyczne, jak i psychiatryczne. W trakcie pobytu na oddziale nefrologii zmodyfikowano leczenie immunosupresyjne (konwersja Prografu na Certican), stosując początkowo minimalne dawki leków, zmieniono leczenie przeciwkrzepliwe oraz ustalono termin ponownego przyjęcia do szpitala celem oceny stanu somatycznego. Po ponownym przyjęciu na oddział nefrologii, wobec braku poprawy stanu psychicznego pacjentki oraz złej tolerancji leczenia immunosupresyjnego, zadecydowano o włączeniu wcześniej przyjmowanych leków zapobiegających odrzuceniu przeszczepu. Kobieta odmówiła ponownej hospitalizacji na oddziale psychiatrii w celu oceny stanu psychicznego. Wobec braku wskazań do hospitalizacji wbrew woli pacjentki została ona wypisana do domu. Na przełomie stycznia i lutego 2017 r. kobieta zgłosiła się do przyklinicznej Poradni Zdrowia Psychicznego w celu otrzymania zaświadczenia o zdolności do pracy. Podczas rozmowy z lekarzem przyznała, że niezwłocznie po poprzedniej hospitalizacji na oddziale psychiatrii samowolnie zmniejszała dawki przyjmowanych leków, a następnie całkowicie zaprzestała ich przyjmowania. Powodem, jak podaje, było złe samopoczucie, poczucie niewydolności psychofizycznej oraz fakt, iż „wszystko, co ją spotkało, jest winą ludzi, a nie chorobą psychiczną". Pacjentce zaproponowano hospitalizację psychiatryczną (VII hospitalizacja psychiatryczna), na którą bardzo niechętnie wyraziła zgodę. W trakcie hospitalizacji pacjentka była nieufna w stosunku do wdrożonego leczenia (aripirazol w początkowej dawce 7,5 mg/d). Po podaniu pierwszej dawki leku zgłaszała objawy niepożądane w postaci poczucia niewydolności psychofizycznej, jednocześnie obserwowano zwiększoną aktywność i polepszenie nastroju, czemu sama pacjentka zaprzeczała. Po zwiększeniu dawki do $15 \mathrm{mg} / \mathrm{d}$ zaczęła zgłaszać niepokój psychoruchowy, uczucie sztywności i napięcia. Zdecydowano o zmniejszeniu dawki leku, a następnie odstawiono go całkowicie. Pacjentce zaproponowano włączenie do leczenia Tiaprydu. Początkowo podawano go w dawce $25 \mathrm{mg} / \mathrm{d}$, następnie po mniej więcej tygodniu - $50 \mathrm{mg} / \mathrm{d}$. Kobieta stała się spokojniejsza, stonowana w zachowaniu, jednak w dalszym ciągu urojeniowo interpretowała sygnały z otoczenia. Swoim zachowaniem na oddziale nie zdradzała obecności objawów psychotycznych jak omamy czy urojenia, przeczyła obecności myśli rezygnacyjnych i samobójczych. W dalszym ciągu była bezkrytyczna wobec swojego stanu zdrowia. Zadecydowano o wypisie pacjentki do domu, ustalono termin ponownego przyjęcia po okresie ok. 2 tyg. w celu ponownej oceny stanu psychicznego oraz ewentualnej modyfikacji leczenia farmakologicznego. Zgodnie z zaleceniem kobieta po 2 tyg. zgłosiła się w celu hospitalizacji. W trakcie pobytu na oddziale psychiatrycznym (VIII hospitalizacja psychiatryczna) na podstawie obserwacji stwierdzono, że była zdecydowanie spokojniejsza w zachowaniu, w nastroju wyrównanym, afektywnie dostosowana, nie zgłaszała sytuacji, w których czuła się prześladowana bądź też obrażana podczas 2-tygodniowego pobytu w domu. Podjęto decyzję o zwiększeniu dawki Tiaprydu do $75 \mathrm{mg} / \mathrm{d}$. W związku z uzyskaną poprawą pacjentkę wypisano do domu. Po upływie ok. 3 tyg., podczas kontrolnej wizyty w Poradni Zdrowia Psychicznego, kobieta deklarowała, iż regularnie przyjmuje zalecone leki. Jednocześnie zgłaszała skargi na poczucie niewydolności psychofizycznej oraz skarżyła się na dalsze prześladowanie w swoim miejscu zamieszkania.

\section{WNIOSKI}

Po przeanalizowaniu całości dostępnych danych z obserwacji zachowania pacjentki na oddziale, z przeprowadzonych badań psychologicznych oraz wykonanych badań obrazowych rozpoznano zgodnie z klasyfikacją ICD 10 - organiczne zaburzenia urojeniowe (Fo6.2). Analizując przebieg choroby, nie można nie zauważyć związku czasowego pojawienia się objawów psychotycznych (urojeń ksobnych, prześladowczych, 
halucynacji słuchowych) z włączeniem leczenia immunosupresyjnego. Pomimo to modyfikacja leczenia immunosupresyjnego (redukcja dawki) nie wpłynęła na poprawę stanu psychicznego kobiety. Pod uwagę wziąć należy brak współpracy ze strony pacjentki, postawę negatywizmu oraz krótki okres stosowania innej terapii immunosupresyjnej. Zmiany w stanie psychicznym wiążące się ze zmianą stosowanych leków oceniać należałoby w perspektywie kilku miesięcy, nie zaś kilku tygodni - co wymuszone było postawą kobiety. W związku z tym nie można w sposób jednoznaczny uznać, iż wystąpienie objawów psychotycznych u pacjentki było bezpośrednio związane z leczeniem immunosupresyjnym. Wydaje się, że to zagadnienie wymaga dalszych szczegółowych badań i obserwacji.

U kobiety na podstawie przeprowadzonych badań stwierdzono obecność APRA. Przeciwciała te są charakterystyczne dla przebiegu tocznia rumieniowatego układowego z objawami neuropsychiatrycznymi. W grupie pacjentów z przedstawionym rozpoznaniem przeciwciała APRA występują z częstością 45-90\%, jednak są one związane z objawami obserwowanymi w przypadku ciężkiej depresji [18]. Pacjentka w żadnym momencie nie spełniała kryteriów układowej choroby tkanki łącznej, w tym tocznia rumieniowatego układowego. Z powodu przyjmowanych przez nią sterydów i leków immunosupresyjnych, które są niezbędne przy przeszczepie nerki, nie jest możliwe stwierdzenie, czy oznaczenie poziomu przeciwciał przed ich zastosowaniem przyniosłoby podobne wyniki. Wdrożone leczenie może maskować również kliniczne manifestacje choroby tkanki łącznej. Wymaga to więc dalszej obserwacji.

Opisywany przypadek stanowi przykład wieloczynnikowej etiologii objawów psychopatologicznych oraz wskazuje na konieczność uwzględniania wielu aspektów stanu somatycznego przy ustalaniu diagnozy psychiatrycznej i planowaniu leczenia pacjenta.

\section{PIŚMIENNICTWO}

1. Król E, Rutkowski B, Czekalski S. Wczesne wykrywanie chorób nerek - wstępne wyniki programu pilotażowego. Przegl Lek 2005;62:690-3.

2. Rutkowski B. Przewlekła choroba nerek (PChN) - wyzwanie XXI wieku. Przegl Lek 2007;2:80-8.
3. Mathis AS, Liu MT, Adamson RT, Nambi SS, Patel AM. Retrospective analysis of early steroid - induced adverse reactions in kidney and kidney pancreas transplant recipients. Transplantat Proc 2007;39(1):199-201. doi: 10.1016/j.transproceed.2006.10.011.

4. Kizilisik AT, Shokouh-Amiri MH, Tombazzi CR, Desmukh S, Grewal HP, Vera SR, et al. Psychiatric complications after liver transplantation. Transplant Proc 2001;33(7-8):3697.

5. Cukor D, Cohen SD, Peterson RA, Kimmel PL. Psychosocial aspects of chronic disease: ESRD as a paradigmatic illness. J Am Soc Nephrol 2007;18(12):3042-55. doi: 10.1681/ASN.2007030345.

6. Christensen AJ, Turner CW, Smith TW, Holman JM, Gregory MC. Health locus of control and depression in end-stage renal disease. J Consult Clin Psychol 1991;59(3):419-24.

7. Zalai D, Szeifert L, Novak M. Psychological distress and depression in patients with chronic kidney disease. Semin Dial 2012;25(4):428-38. doi: 10.1111/j.1525-139X.2012.01100.x.

8. DiMartini A, Crone C, Fireman M, Dew MA. Psychiatric aspects of organ transplantation in critical care. Crit Care Clin 2008;24(4):949-81. doi: 10.1016/j.ccc.2008.05.001.

9. Noohi S, Khaghani-Zadeh M, Javadipour M, Assari S, Najafi M, Ebrahiminia $\mathrm{M}$, et al. Anxiety and depression are correlated with higher morbidity after kidney transplantation. Transplant Proc 2007;39(4):1074-8. doi: 10.1016/j.transproceed.2007.04.002.

10. Novak M, Molnar MZ, Szeifert L, Kovacs AZ, Vamos PE, Zoller R, et al. Depressive symptoms and mortality in patients after kidney transplantation: a prospective prevalent cohort study. Psychosom Med 2010;72(6):52734. doi: 10.1097/PSY.0b013e3181dbbb7d.

11. Corbett C, Armstrong MJ, Parker R, Webb K, Neuberger JM. Mental health disorders and solid-organ transplant recipients. Transplantation 2013;96(7):593-600. doi: 10.1097/TP.0b013e31829584e0.

12. Corruble E, Barry C, Varescon I, Durrbach A, Samuel D, Lang P, et al. Report of depressive symptoms on waiting list and mortality after liver and kidney transplantation: a prospective cohort study. BMC Psychiatry 2011;11:182. doi: 10.1186/1471-244X-11-182.

13. Arapaslan B, Soykan A, Soykan C, Kumbasar H. Cross-sectional assessment of psychiatric disorders in renal transplantation patients in Turkey: a preliminary study. Transplant Proc 2004;36(5):1419-21. doi: 10.1016/j. transproceed.2004.04.087.

14. Levy NB. What is psychonephrology? J Nephrol 2008;21(Suppl 13): 51-3.

15. Abbott KC, Agodoa LY, O'Malley PG. Hospitalized psychoses after renal transplantation in the United States: incidence, risk factors, and prognosis. J Am Soc Nephrol 2003;14(6):1628-35.

16. Heinrich TW, Marcangelo M. Psychiatric issues in solid organ transplantation. Harv Rev Psychiatry 2009;17(6):398-406. doi: 10.3109/ 10673220903463259.

17. Akman B, Ozdemir FN, Sezer S, Micozkadioglu H, Haberal M. Depression levels before and after renal transplantation. Transplant Proc 2004;36(1):111-3. doi: 10.1016/j.transproceed.2003.11.021.

18. Brzosko M, editor. Reumatologia kliniczna. Szczecin: Wydawnictwo Pomorskiego Uniwersytetu Medycznego w Szczecinie; 2010. 